\title{
Measurement of radon exhalation from soil samples in various fault regions of Aizawl district, Mizoram, India
}

\author{
Laldingngheta ${ }^{1}$, Vanramlawma ${ }^{1}$, Hmingchungnunga ${ }^{1}$, L.Z. Chhangte ${ }^{1}$, R.C Tiwari ${ }^{1}$,

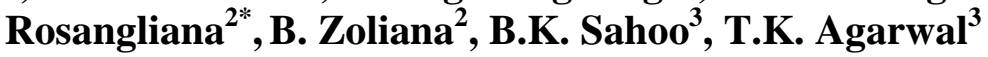 \\ ${ }^{1}$ Department of Physics, Mizoram University, Tanhril 796004, Mizoram, India \\ ${ }^{2}$ Department of Physics, Government Zirtiri Residential Science College, Aizawl 796007, Mizoram, India \\ ${ }^{3}$ Radiological Physics and Advisory Division, Bhabha Atomic Research Centre, Mumbai 400085, India \\ *Corresponding author: rslct7@gmail.com
}

\begin{abstract}
Radon is a highly radioactive, colourless, chemically unreactive and is produced from the natural decay of uranium. As it is being synthesized, it can be released into air or water-containing pores between soil and rock particles. Environmental radon is of great medical concern as it causes dangerous health problems such as lung cancer, and is classified as Group A carcinogen. Measurement of radon mass exhalation rate was performed on soil samples collected from 33 different sites within different fault regions of Aizawl district, Mizoram, India, using Smart RnDuo. The sampling sites are located within the region $23^{\circ} 22^{\prime} 39.5^{\prime \prime} \mathrm{N}$ to $24^{\circ}$ $09^{\prime} 30.16^{\prime \prime} \mathrm{N}$ latitude and $92^{\circ} 39^{\prime} 49.03^{\prime \prime} \mathrm{E}$ to $92^{\circ} 56^{\prime} 49.35^{\prime \prime} \mathrm{E}$ longitude. Soil samples were collected from three different points in each selected fault with a minimum of $200 \mathrm{~m}$ from each other. The type of soil collected from these regions was identified using mechanical sieve shaker and the result obtained was found to be mostly sandy type of soil for all the soil samples. The radon mass exhalation rate in soil was found to be in the range of $11.2 \mathrm{mBq} / \mathrm{kg} / \mathrm{hr}$ to $72.2 \mathrm{mBq} / \mathrm{kg} / \mathrm{hr}$, with an average of $39.92 \mathrm{mBq} / \mathrm{kg} / \mathrm{hr}$. It was observed that radon mass exhalation rate is higher in fault regions of Aizawl district as compared to other regions of India such as northern Rajasthan, Kangra District, Himachal Pradesh and Kathmandu Valley, Nepal.
\end{abstract}

Keywords: Radon exhalation, mass exhalation, Smart RnDuo, fault regions, soil samples.

\section{INTRODUCTION}

Radon is a highly radioactive, colourless, chemically unreactive inert gas formed on the fourteenth step of sequence of ${ }^{238} \mathrm{U}$ radioactive decay series. Radon is being continuously formed in the soil and released in air. The concentration of radon in soil is influenced by soil moisture content, barometric pressure variations, temperature and structure of soil. The transportation of radon from the source to the environment (gas or liquid medium) is accomplished by the process called emanation in which radon is released into small air or water contained in pores between soil and rock particles which is facilitated by diffusion and convection. Radon and thoron are usually produced in soil as a result of the presence of ${ }^{238} \mathrm{U}$ and ${ }^{232} \mathrm{Th}$ containing minerals. Radon or thoron in the earth's crust or other porous matrix is free to move only if its atoms find their way into pores or capillaries.
In this work, the radon exhalation from soil samples collected from various fault regions of Aizawl district, Mizoram, is measured and is compared with the exhalation of radon in some parts of India. The type of soil collected is also identified using mechanical sieve shaker.

\section{Materials AND Methods}

Mizoram lies in the seismic zone $\mathrm{V}$ of seismic zonation map of India. Figure 1 shows the geographical sites where the soil samples were collected. The state of Mizoram is a hilly area with an average elevation of about 1000 meters to 1300 meters from sea level. It is a tropical region with moderate climate and the temperature varies from $11^{\circ} \mathrm{C}$ to $24^{\circ} \mathrm{C}$ during the winter season and $18^{\circ} \mathrm{C}$ to $29^{\circ} \mathrm{C}$ during summer. The sampling area extends from $23^{\circ} 22^{\prime} 39.5^{\prime \prime} \mathrm{N}$ to $24^{\circ} 09^{\prime} 30.16^{\prime \prime} \mathrm{N}$ latitude and $92^{\circ} 39^{\prime} 49.03^{\prime \prime} \mathrm{E}$ to $92^{\circ} 56^{\prime} 49.35^{\prime \prime} \mathrm{E}$ longitude. Soil samples 
were collected from 33 different locations within the study area. Radon content in soil was obtained by means of scintillation cell method using Smart RnDuo. Soil samples were collected in with the help of simple gardening tools.

Soil was collected from the different fault regions. For each fault line, three samples of soil within a minimum distance of $200 \mathrm{~m}$ from each other were collected.

The detector used, RnDuo is a technologicallyadvanced portable continuous radon/thoron monitor, designed for multiple applications in radon and thoron studies. For radon measurements, sample gas is collected into a scintillation cell $(150 \mathrm{cc})$ by diffusion process. During diffusive sampling, the gas passes through a "progeny filter" and "thoron discriminator" eliminating radon/thoron progenies and thoron. The thoron discriminator based on "diffusion-time delay" does not allow the short lived thoron 220Rn (half-life 55.6 s) to pass thorough. The radon measurements in RnDuo are based on detection of alpha emitted from radon and its decay products formed inside a scintillation cell volume. The alpha scintillations from radon and its decay products formed inside the cell are continuously counted by the PMT and the associated counting electronics.

To measure radon in soil, firstly the volume and mass of each sample to be measured are taken. The sample is then filled in the radon exhalation chamber and closed using the detector as shown in Figure 2. The detector is connected to the Smart RnDuo by means of a signal cable. The samples are then measured by mass exhalation method using the Smart RnDuo with a cycle of 60 minutes for a minimum of period of 8 hours. The pump is set OFF on this mode. Build up data of radon with elapsed time can be retrieved and least square fitting can be carried out using the equation:

$$
C(t)=\left(\frac{J_{m} M}{V}\right) t+C_{o}
$$

Where $C(t)$ is ${ }^{222} R n$ concentration $\left(B q m^{-3}\right.$ ) at time $t, C_{o}$ is the ${ }^{222} \mathrm{Rn}$ concentration $\left(\mathrm{Bq} \mathrm{m}{ }^{-3}\right)$ present in the chamber volume at $t=0, M$ is the total mass of the dry sample $(\mathrm{Kg}) . \mathrm{V}$ is the effective volume (volume of detector + porous volume of sample + residual air volume of mass exhalation chamber) $\left(\mathrm{m}^{3}\right)$. The porous volume $\left(\mathrm{V}_{\mathrm{p}}\right)$ can be estimated using the following equation:

$$
V_{P}=V_{s}-\left(\frac{M}{\rho_{g}}\right)
$$

Where $\mathrm{V}_{\mathrm{s}}$ is the sample volume in the mass exhalation chamber. $\rho_{g}$ is the specific gravity of the sample which can be taken as $2.77 \mathrm{gm} / \mathrm{cc}$ for clay type soil material. $t$ is the measurement time $(\mathrm{h})$.

Upon least square fitting of the data to the above equation one may obtain $J_{m}$ from the fitted parameters with the information of the mass $M$ of the sample.
Table 1: Measurement of radon exhalation in soil using RnDuo in fault regions of Aizawl District, Mizoram.

\begin{tabular}{|c|l|c|c|}
\hline No & Name of Location & $\begin{array}{c}\text { Macatio } \\
\text { n code }\end{array}$ & $\begin{array}{c}\text { exhalation } \\
\text { rate } \\
\text { (mBq/kg/ } \\
\text { hr) }\end{array}$ \\
\hline 1. & Thiak-Samlukhai 1 Location1 & A1 & 27.9 \\
\hline 2. & Thiak-Samlukhai 1 Location2 & A2 & 29.2 \\
\hline 3. & Thiak-Samlukhai 1 Location3 & A3 & 38.1 \\
\hline 4. & Tuirial 1 & A4 & 35.1 \\
\hline 5. & Tuirial 2 & A5 & 45.9 \\
\hline 6. & Tuirial 3 & A6 & 33.5 \\
\hline 7. & Ratu 1 & A7 & 72.2 \\
\hline 8. & Ratu 2 & A8 & 59.7 \\
\hline 9. & Ratu 3 & A9 & 33.6 \\
\hline 10. & Thiak-Samlukhai 2 Location1 & A10 & 51.2 \\
\hline 11. & Thiak-Samlukhai 2 Location2 & A11 & 48.2 \\
\hline 12. & Thiak-Samlukhai 2 Location3 & A12 & 46.9 \\
\hline 13. & Sailam-Sialsuk Junction 1 & A13 & 34.2 \\
\hline 14. & Sailam-Sialsuk Junction 2 & A14 & 15.5 \\
\hline 15. & Sailam-Sialsuk Junction 3 & A15 & 44.7 \\
\hline 16. & Lungsum-Vervek 1 & A16 & 46.4 \\
\hline 17. & Lungsum-Vervek 2 & A17 & 31.7 \\
\hline 18. & Lungsum-Vervek 3 & A18 & 30.6 \\
\hline 19. & Tuirinikai 1 & A19 & 11.2 \\
\hline 20. & Tuirinikai 2 & A20 & 30.2 \\
\hline 21. & Tuirinikai 3 & A21 & 43.5 \\
\hline 22. & E. Phaileng-Suangpuilawn 1 & A22 & 38.4 \\
\hline 23. & E. Phaileng-Suangpuilawn 2 & A23 & 46.7 \\
\hline 24. & E. Phaileng-Suangpuilawn 3 & A24 & 39.7 \\
\hline 25. & Muallungthu 1 & A25 & 35.4 \\
\hline 26. & Muallungthu 2 & A26 & 39.6 \\
\hline 27. & Muallungthu 3 & A27 & 21.3 \\
\hline 28. & Lungleng 1 & A28 & 44.2 \\
\hline 29. & Lungleng 2 & 69.4 \\
\hline 30. & Lungleng 3 & 53.6 \\
\hline 31. & Samtlang 1 & A29 & 46.8 \\
\hline 32. & Samtlang 2 & Samtlang 3 & 28.7 \\
\hline 33. & & \\
\hline & & A32.3 \\
\hline
\end{tabular}

Table 2: Identification of soil type in different soil samples from fault regions of Aizawl district.

\begin{tabular}{|c|l|c|c|c|}
\hline \multirow{2}{*}{$\begin{array}{c}\text { Sl. } \\
\text { no }\end{array}$} & \multicolumn{1}{|c|}{ Locations } & \multicolumn{3}{|c|}{ Percentage of } \\
\cline { 3 - 5 } & & Sand & Silt & Clay \\
\hline 1 & Țhiak-Samlukhai 1 & 86.35 & 9.19 & 3.92 \\
\hline 2 & Țhiak-Samlukhai 2 & 99.43 & 0.28 & 0.07 \\
\hline 3 & Ratu & 99.93 & 0.01 & 0.00 \\
\hline 4 & Tuirial & 95.27 & 3.51 & 1.14 \\
\hline 5 & Sailam-Sialsuk Junction 1 & 93.35 & 4.48 & 1.57 \\
\hline 6 & East Phaileng-Suangpuilawn & 96.77 & 1.71 & 1.50 \\
\hline 7 & Lungleng & 94.30 & 3.20 & 2.18 \\
\hline 8 & Muallungthu & 98.86 & 0.58 & 0.09 \\
\hline 9 & Lungsum-Vervek & 97.12 & 1.67 & 0.99 \\
\hline 10 & Samtlang & 99.03 & 0.56 & 0.19 \\
\hline 11 & Tuirinikai & 90.23 & 3.83 & 5.73 \\
\hline
\end{tabular}


Figure 1: Map of Mizoram showing location of sampling sites.

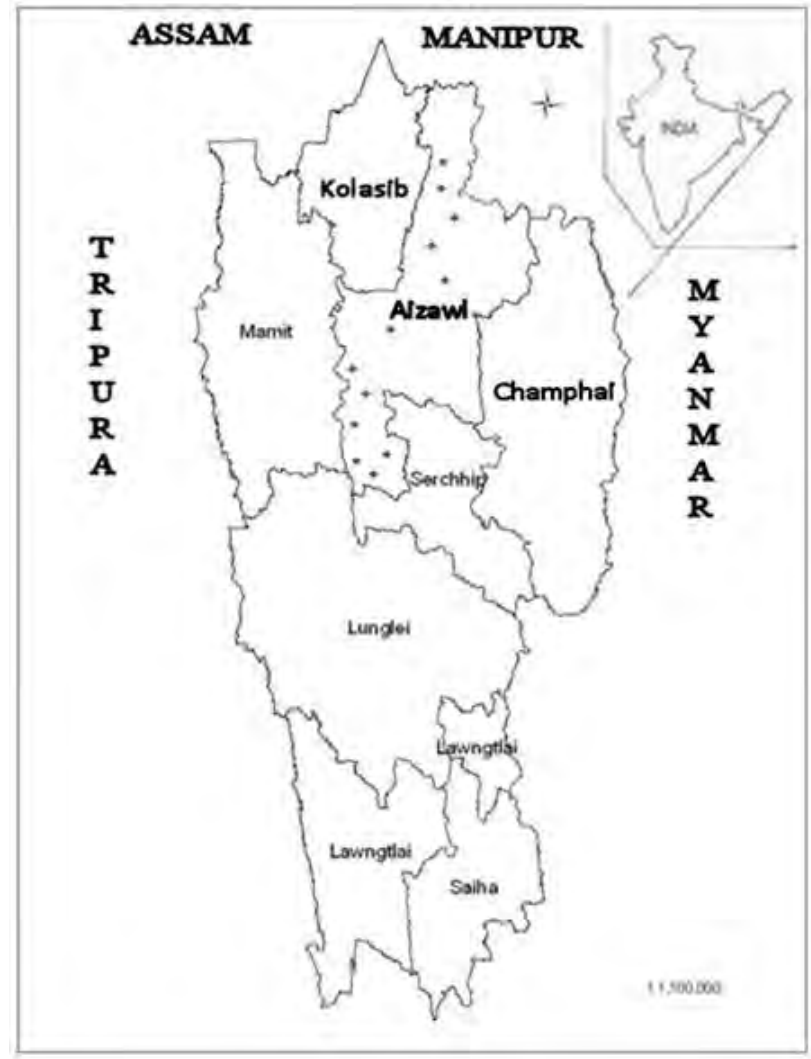

Figure 2: Schematic representation of measurement of radon mass exhalation in soil using Smart RnDuo.
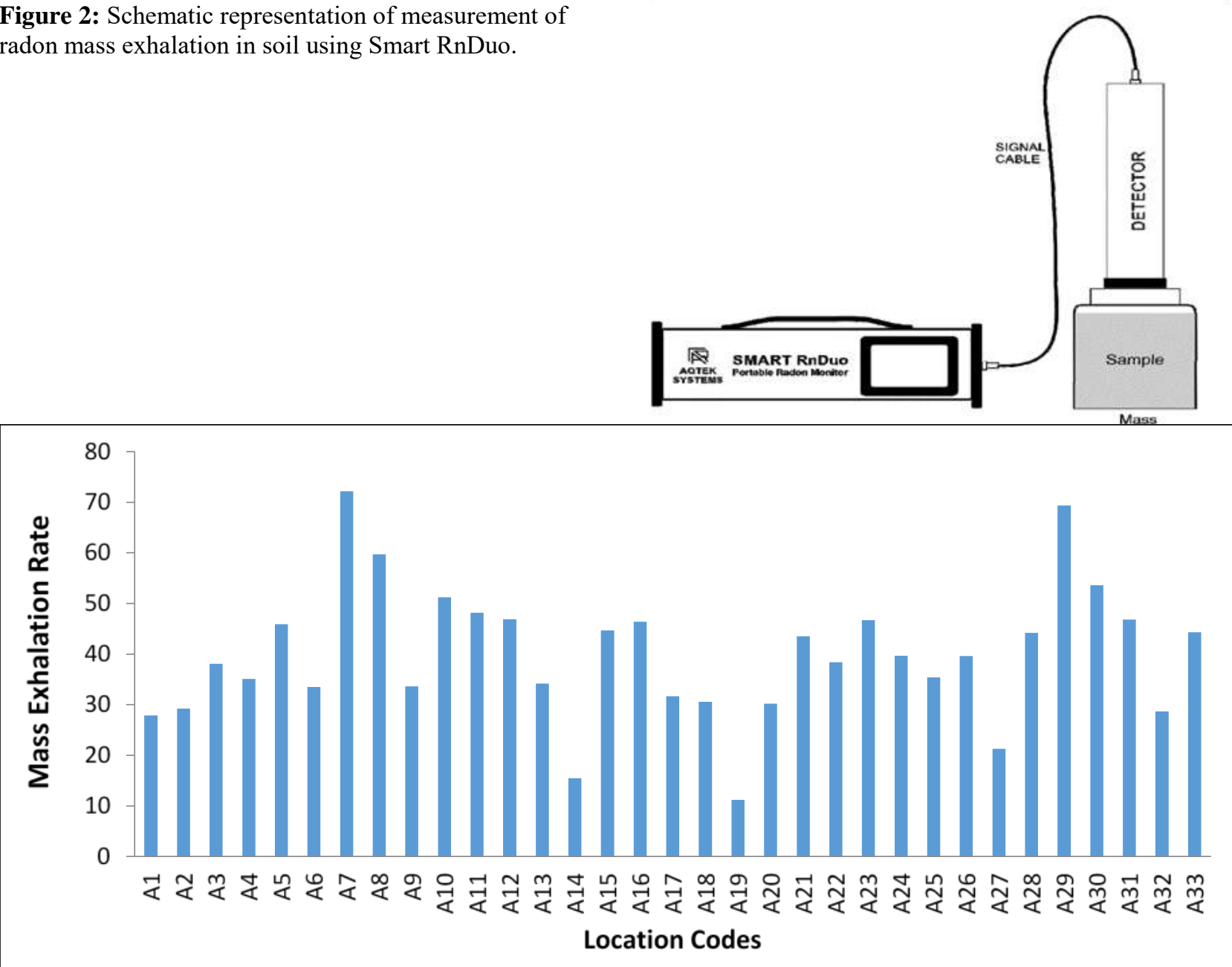

Figure 3: Radon exhalation in soil samples of fault regions in Aizawl district, Mizoram. 


\section{RESULTS}

In this study area as shown in Figure 1, a total of 33 locations were selected from Aizawl district. The radon content in soil was found to be varying from $11.2 \mathrm{mBq} /$ $\mathrm{kg} / \mathrm{hr}$ to $72.2 \mathrm{mBq} / \mathrm{kg} / \mathrm{hr}$ with an average of $39.927 \mathrm{mBq} /$ $\mathrm{kg} / \mathrm{hr}$.

Figure 3 shows the comparison of radon exhalation of different soil samples taken from various faults in Aizawl district. It can be seen that radon exhalation was found to be highest in A7 and lowest in A19.

\section{DiscUSSION}

In Aizawl district, the values of radon exhalation in soil samples from fault regions ranges between 11.2 and $72.2 \mathrm{mBq} / \mathrm{kg} / \mathrm{hr}$ with an average of $39.92 \mathrm{mBq} / \mathrm{kg} / \mathrm{hr}$. Therefore, radon exhalation is high in fault regions of Aizawl district as compared to some regions of India like Northern Rajasthan (14.96 mBq/kg/hr) (Duggal et. al., 2015), Kangra district, Himachal Pradesh (19.91 mBq/kg/ hr) (Sharma et. al., 2003) and Kathmandu Valley, Nepal (6.4 mBq/kg/hr) (Purajuli et. al., 2015). The results in different regions may vary because rainfall, snowfall, freezing and increase in atmospheric pressure results in decrease of exhalation rate, whereas increase in wind speed and temperature can increase it.

Also radon exhalation increases with moisture content up to $8 \%$ and starts decreasing if water content is increased further (Faheem et al., 2008; Hosoda et al., 2007). The results obtained from this may be used as reference for further studies. The type of soil collected from these regions was analyzed using Mechanical Sieve shaker and the results obtained were found to be mostly sand type of soil for all the soil samples.

\section{ACKNOWLEDGEMENT}

The authors would like to acknowledge the Board of Research in Nuclear Sciences, Department of Atomic Energy, Government of India, for providing financial assistance through the Research Project.

\section{REFERENCES}

Duggal, V., Mehra, R., Rani, A. (2015). Study of radium and radon exhalation rate in soil samples from areas of northern Rajasthan. Journal of the Geological Society of India, 86(3), 331-336.

Faheem, M. (2008). Radon exhalation and its dependence on moisture content from samples of soil and building materials. Radiation Measurements, 43(8), 1458-1462.

Hosoda, M., Shimo, M., Sugino, M., Furukawa, M., Fukushi, M. (2007). Effect of soil moisture content on radon and thoron exhalation. Journal of Nuclear Science and Technology, 44(4), 664-672.

Parajuli, P., Thapa, D., Shah, B. R. (2015). Study of radon exhalation rate in soil samples of Kathmandu valley using passive detector LR115. Inter J Chem Phys Sci, 4 (4), 3-9.

Sharma, D. K., Kumar, A., Kumar, M., Singh, S. (2003). Study of uranium, radium and radon exhalation rate in soil samples from some areas of Kangra district, Himachal Pradesh, India using solid-state nuclear track detectors. Radiation Measurements, 36(1-6), 363-366. 